\title{
Tectonic inheritance at a continental margin
}

\author{
William A. Thomas, Department of Geological Sciences, University of Kentucky, \\ Lexington, Kentucky 40506-0053, USA, geowat@uky.edu
}

\section{INTRODUCTION}

Forty years ago, the eastern margin of North America inspired Tuzo Wilson (1966) to ask, "Did the Atlantic close and then re-open?" The Wilson cycle of closing and opening of ocean basins incorporates the cyclic assembly and breakup of supercontinents. Alternate processes of extension and compression of continental margins suggest an important potential for tectonic inheritance and overprinting.

Now, we recognize a succession of two complete Wilson cycles in eastern North America: closing of an ocean and assembly of the Rodinia supercontinent, breakup of Rodinia and opening of the Iapetus Ocean, closing of Iapetus and assembly of the Pangaea supercontinent, and breakup of Pangaea and opening of the Atlantic Ocean (Fig. 1). Precambrian rocks of cratonic North America indicate less well-defined, earlier cycles. Tectonic inheritance at a range of scales has been recognized in the successive continental margins preserved within the crust of present eastern North America, posing several fundamental questions. Does each episode of supercontinent assembly and breakup adapt to the tectonic framework of a preexisting continental margin and, in turn, leave a mold for the next episode? Is tectonic inheritance through successive Wilson cycles a first-order constraint on the processes through which continental crust is accumulated and continental fabrics evolve? Does tectonic inheritance in the shallow crustal structures reflect a pervasive fabric of the deeper lithosphere?

\section{ASSEMBLY OF RODINIA (THE GRENVILLE OROGEN)}

Metamorphic and igneous rocks of the Grenville province, ranging in age from ca. 1350 to $1000 \mathrm{Ma}$, record closing of an ocean and assembly of the Rodinia supercontinent (e.g., Hoffman, 1991). The long span of ages suggests multiple events during which multiple elements were swept up and sutured successively to cratonic protoLaurentia (e.g., McLelland et al., 1996; Mosher, 1998).
The Grenville front, at the leading edge of the province, is mapped through generally broad curves along the outcrop in Canada and southward with decreasing resolution in the subsurface, using drill and geophysical data, approximately to central Tennessee; subsurface data define a separate segment in Texas (Figs. 1 and 2). No data presently are available to locate the Grenville front precisely beneath a thick sedimentary cover in the Mississippi Embayment of the Mesozoic-Cenozoic Gulf Coastal Plain; however, the trace must accommodate a substantial dextral bend between the mapped Grenville (Llano) front in Texas and the approximately located trace in the subsurface in central Tennessee (Fig. 2).
The pre-Rodinia (pre-Grenville) continental margin is unknown; however, the dextral bend of the Grenville front beneath the Gulf Coastal Plain suggests possible inheritance from a dextral offset in the older continental margin. Northwest-striking dikes (ca. $1350 \mathrm{Ma}$ ) in Oklahoma (Denison, 1982) parallel the trend of the dextral bend of the Grenville front and suggest the possible orientation of the offset of the older rifted continental margin (Fig. 2). Few other hints are available to suggest the trace of the pre-Rodinia rifted margin of cratonic proto-Laurentia. The Grenville front truncates internal tectonic fabrics within, and boundaries between, several older provinces, from the Archean Superior province to the 1500-1300-Ma

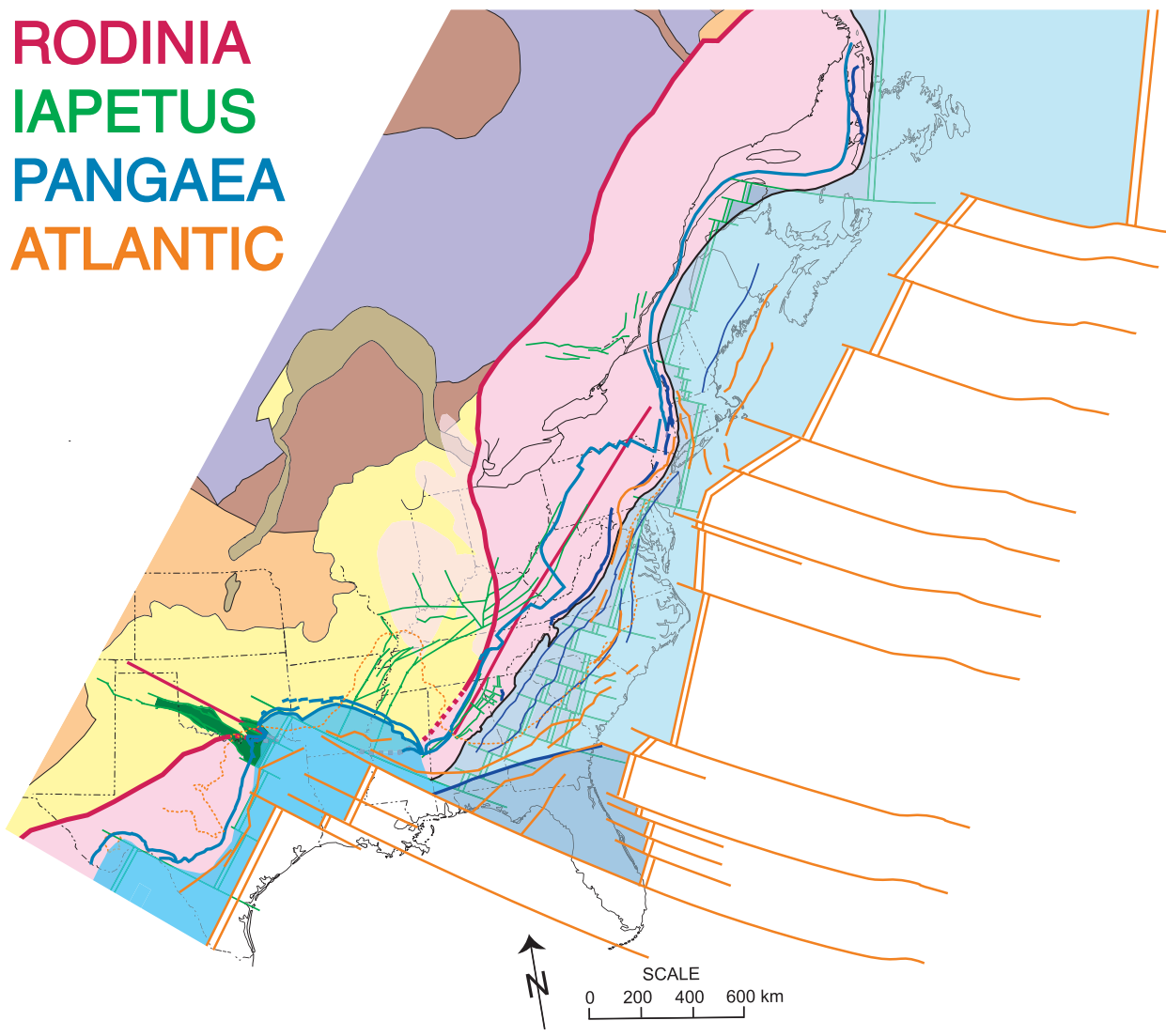

Figure 1. Map showing the record of tectonic inheritance through two complete Wilson cycles in eastern North America (compiled from Figs. 2-5). Assembly of Rodinia, opening of the lapetus Ocean, assembly of Pangaea, and opening of the Atlantic Ocean are color-coded on this map and in Figures 2-5. 
Granite-Rhyolite province (Fig. 2), which have distinct ages and tectonic origins. Fabrics from older cycles of tectonic accretion may hold clues to the trace of the pre-Rodinia margin, perhaps extending tectonic inheritance during cyclic assembly and breakup of supercontinents back in time to the Archean cratons.

Sedimentary deposits in the Grenville foreland in Ohio and Kentucky (Fig. 2) are interpreted to record filling of an intracratonic rift system (Drahovzal et al., 1992) or, alternatively, a synorogenic foreland basin (Santos et al., 2002), possibly a broken foreland. Further resolution of the structure of the Grenville foreland may help to constrain the shape of the pre-Rodinia rifted margin by analogy with younger foreland basins that have distinct tectonic inheritance from the preceding rifted margin.

The range of ages and compositions of Grenville rocks, variations in $\mathrm{Pb}$ isotopic ratios, and tectonic fabrics indicate intraGrenville sutures, consistent with multiple accreted terranes and conjugate continental margins within the assembly of Rodinia (e.g., McLelland et al., 1996; Hatcher et al., 2004). One possible intra-Grenville suture, the New York-Alabama magnetic lineament (King and Zietz, 1978), has a nearly straight trace that may reflect either accretion along a straight segment of the preGrenville rifted margin of proto-Laurentia, accretion at a margin already smoothed by accreted terranes, or orogen-parallel slip cutting across the shape of the margin. A Grenville age and $\mathrm{Pb}$ isotopic ratios link the basement rocks of the Argentine Precordillera terrane to Laurentia (Kay et al., 1996), indicating that rifting during breakup of Rodinia cut across intra-Grenville sutures.

\section{BREAKUP OF RODINIA AND OPENING OF THE IAPETUS OCEAN}

Synrift sedimentary and igneous rocks, a post-rift unconformity, and early post-rift sedimentary strata document the breakup of Rodinia, the opening of the Iapetus Ocean, and the isolation of Laurentia by Cambrian time (ca. $530 \mathrm{Ma}$ ). A range of ages (e.g., Aleinikoff et al., 1995; Hogan and Gilbert, 1998; Thomas et al., 2000; Cawood and Nemchin, 2001; Owens and Tucker, 2003) spans early extension
(760-650 Ma), pervasive rifting (620-545 Ma) along most of the Laurentian margin, and late-stage rifting (540-530 Ma) of microcontinents. Later sedimentary burial and deformation have obscured the trace of the Iapetan rifted margin, segments of which are dispersed in the Appalachian allochthon and Ouachita footwall. Data from outcrop geology, deep wells, and geophysical surveys provide for palinspastic reconstruction of the rift (e.g., Thomas, 1977, 1991; Cawood et al., 2001).

The palinspastically restored Iapetan rifted margin follows an orthogonally zigzag trace defined by northeast-striking rift segments offset by northwest-striking transform faults (Figs. 1 and 3). Intersections of rift segments and transform faults frame promontories (convex oceanward) and embayments ${ }^{1}$ (concave oceanward) of the rifted continental margin. The trace of the Iapetan Alabama-Oklahoma transform corresponds to the probable location of the large-scale dextral bend in the Grenville front, suggesting tectonic inheritance from the shape of the Grenville orogen, as well as from the possible dextral offset in the pre-Rodinia rifted margin of proto-Laurentia and the northwest-striking 1350-Ma dike fabric (Fig. 3). Excepting the Alabama-Oklahoma transform, no tectonic inheritance from Grenville margins, sutures, or other fabrics has been recognized in the Iapetan rift system.

The trace of the Iapetan rifted margin is almost entirely within rocks of the Grenville province, leaving a belt of Grenville rocks along the eastern margin of Laurentia (Fig. 3). Along the Iapetan AlabamaOklahoma transform, however, granite boulders in Ordovician slope deposits have ages (Bowring, 1984) that correspond to the Granite-Rhyolite province, suggesting that the rift and transform in the corner of the Ouachita embayment cut across the Grenville front (Fig. 2). The Iapetan rift evidently cut across intra-Grenville sutures, for example, leaving some isotopically distinct, possibly "non-Laurentian Grenville" rocks of the Blue Ridge attached to "Laurentian Grenville" rocks (Loewy et al., 2002; Hatcher et al., 2004) and transferring the Laurentian Argentine Precordillera terrane to Gondwana (Thomas and Astini, 1996). Further resolution of traces of intra-Grenville sutures and terranes will define additional piercing points for reconstruction of conjugate margins within the assembly of Rodinia.

Contrasts in crustal structure and tectonic history distinguish transform, upperplate-rift, and lower-plate-rift segments along the Iapetan rifted margin of Laurentia, consistent with a low-angle-detachment simple-shear mechanism (Thomas, 1993, Figure 2 therein). Narrow ( $25 \mathrm{~km})$ zones of transitional crust characterize transform faults, which function as vertical fracture zones to offset the rift and to bound domains of opposite dip of the detachment (e.g., Lister et al., 1986). A wide zone $(>200 \mathrm{~km})$ of extended transitional crust with rotated basement graben blocks and thick (>10 km) synrift sediment on a lower-plate rifted margin contrasts with a more narrow zone of transitional crust, general lack of preserved synrift sediment, and a post-rift residual thermal uplift on an upper-plate margin (e.g., Thomas, 1993; Thomas and Astini, 1999). Despite the important contrasts in crustal structure, no clear association with fabrics of Grenville and older rocks indicates tectonic inheritance of the internal style of the Iapetan rift; however, these structures did set the stage for pervasive inheritance during the assembly of Pangaea.

Rift-parallel graben systems (Mississippi Valley, Birmingham, and Rome; Fig. 3) indicate Early to early Late Cambrian, late synrift extension inboard from the rifted margin (Thomas, 1991). A dextral offset from the Mississippi Valley graben to the Rome trough, including the transverse Rough Creek graben, suggests a transform offset of the intracratonic graben systems (Thomas, 1993). Any possible relationship between the intracratonic rift-parallel graben systems and older fabrics is obscure and presently unrecognized; however, like the structures of the rifted margin, these faults provide a mold for tectonic inheritance by later structures. The Southern Oklahoma fault system parallels the Alabama-Oklahoma transform and extends into the Laurentian craton from the Ouachita embayment in the rifted margin (Fig. 3). Bimodal igneous rocks (539-530 Ma) along the Southern Oklahoma fault system (Gilbert and Denison in Van Schmus et al., 1993) suggest a leaky transform, which, like

${ }^{1}$ Originally termed "reentrant" (Thomas, 1977) but changed to "embayment" (Thomas, 1983) to avoid confusion with the term "recess," which denotes a cratonward concave bend in a thrust belt. 


\section{GSA PRESIDENTIAL ADDRESS}

the Alabama-Oklahoma transform, parallels the dextral bend in the Grenville front, the strike of the 1350-Ma dikes, and the possible dextral offset in the pre-Rodinia continental margin, clearly indicating tectonic inheritance.

\section{ASSEMBLY OF PANGAEA (THE APPALACHIAN-OUACHITA OROGEN)}

The Appalachian-Ouachita orogenic belt records the successive, diachronous Taconic (Ordovician-Silurian), Acadian (Devonian-Mississippian), and Alleghanian (Mississippian-Permian) orogenies (Drake et al., 1989; Osberg et al., 1989; Hatcher et al., 1989), culminating in closure of Iapetus and assembly of the Pangaea supercontinent in Permian time. The wellmapped trace of the orogen from Newfoundland to Alabama exhibits sweeping curves of salients (convex cratonward in the direction of tectonic transport) and more angular recesses (concave cratonward) (Fig. 4). Westward from Alabama in the subsurface beneath the Gulf Coastal Plain, deep drill and seismic reflection data, as well as outcrops in the Ouachita Mountains and in the Marathon region of west Texas, document curves of similar magnitude (Thomas et al., 1989).

Appalachian-Ouachita salients are located at embayments of the Iapetan margin, and recesses are on promontories (Rankin, 1976; Thomas, 1976, 1977). The leading part of the thrust belt wrapped around the shape of promontories and embayments of the older rifted margin (Fig. 4), indicating a grand scale of tectonic inheritance. Other specific manifestations of tectonic inheritance are expressed at a range of scales.

Each of the three comprehensive orogenic episodes encompasses substantial along-strike diachroneity, which reflects a systematic relationship to the shape of the Iapetan rifted margin. From the St. Lawrence promontory to the Alabama promontory, a stratigraphically upward transition from shelf carbonates to black shale records Taconic tectonic loading, foreland subsidence, and synorogenic sedimentation (Drake et al., 1989). The times of initial Taconic tectonic loading and foreland subsidence vary systematically in relation to the shape of the Iapetan rifted margin: first, on the St. Lawrence promontory in Newfoundland; next, on the Alabama promontory followed by migration
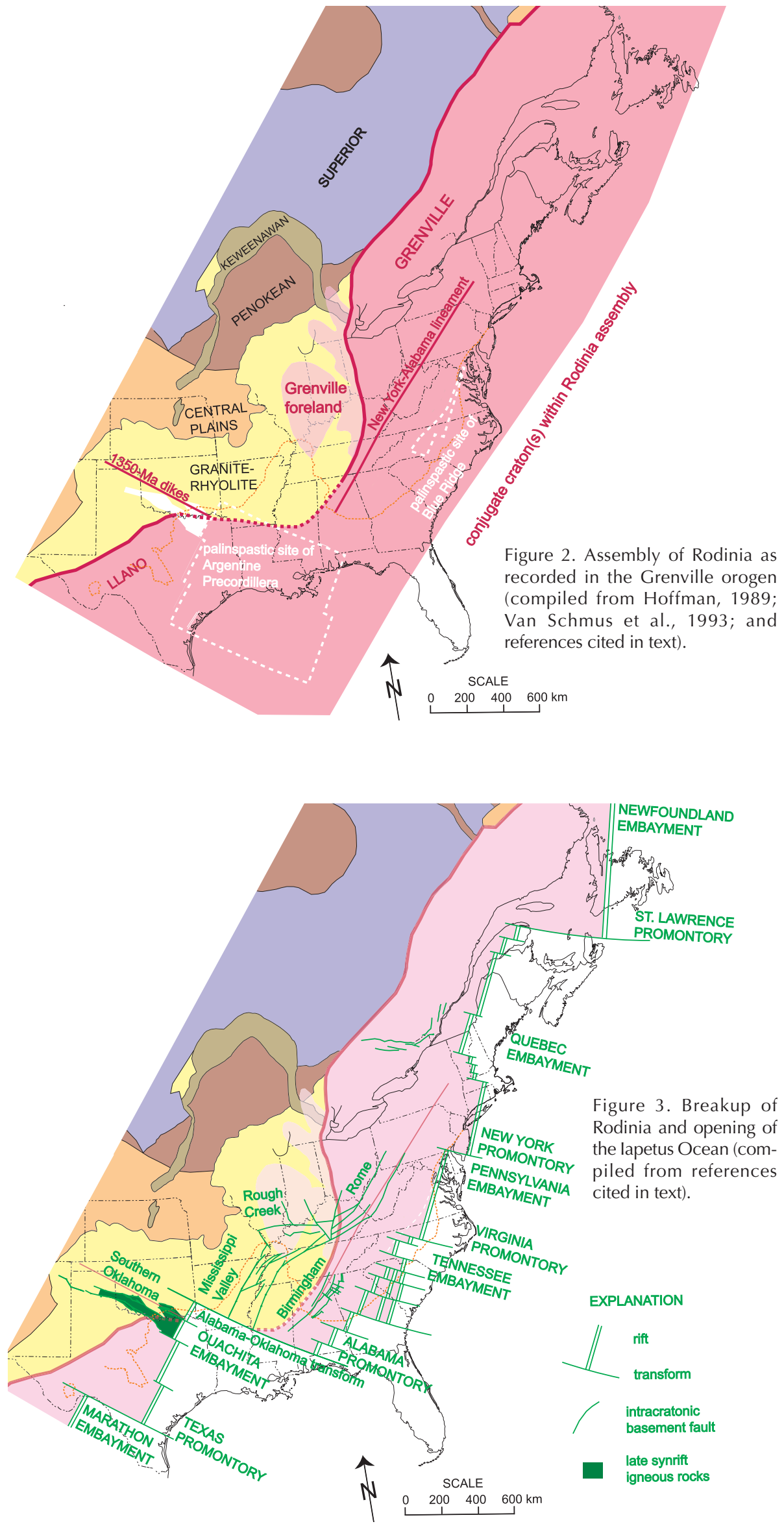


\section{GSA PRESIDENTIAL ADDRESS}
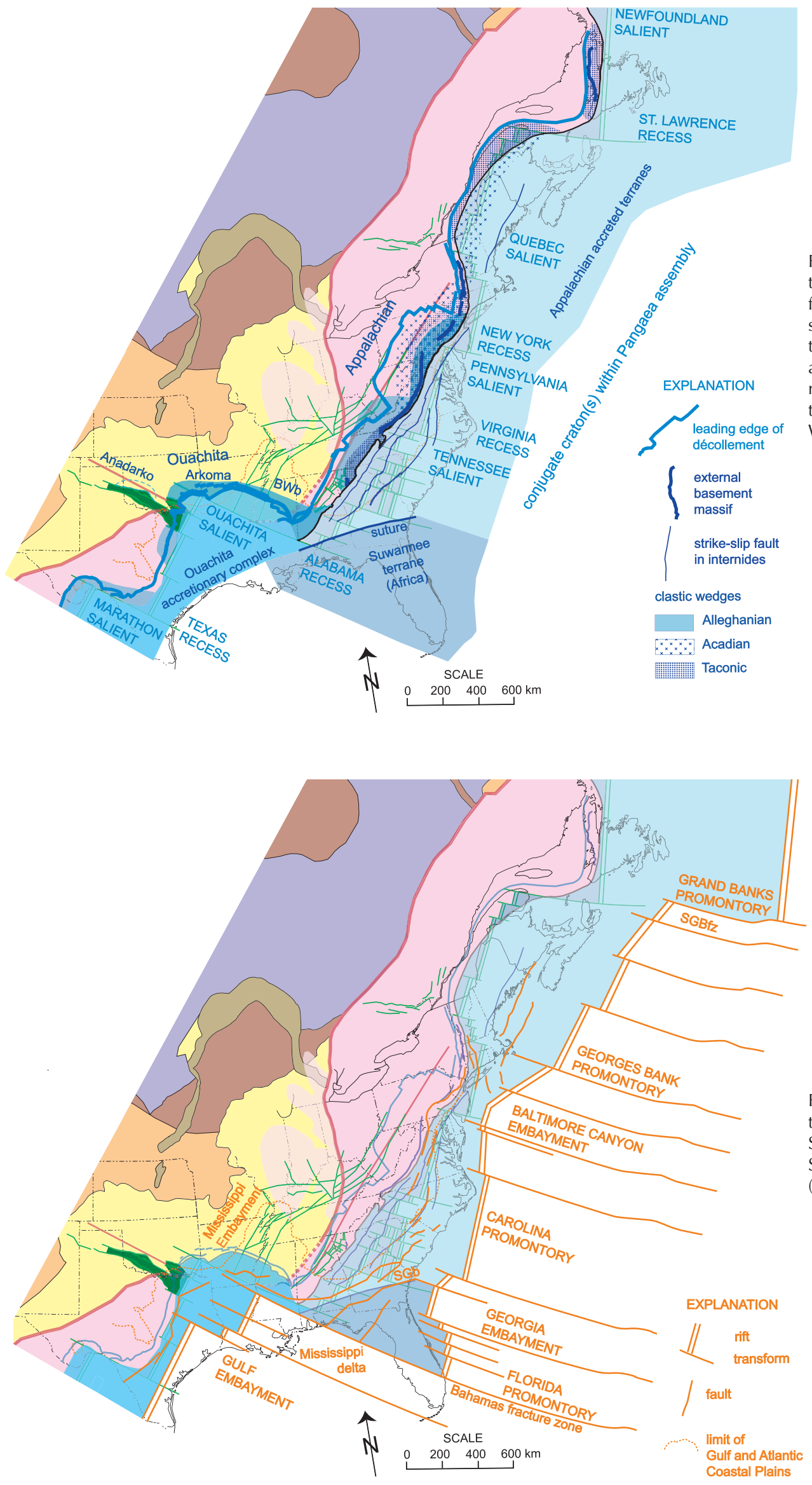

Figure 4. Assembly of Pangaea as recorded in the Appalachian-Ouachita orogen (compiled from references cited in text). Patterns for synorogenic clastic wedges show areas where thickness is $>50 \%$ of the maximum (in present allochthonous position not palinspastically restored); dashed line shows deeper part of the intracratonic Anadarko basin. BWb-Black Warrior basin.
Figure 5. Breakup of Pangaea and opening of the Atlantic Ocean (compiled from Klitgord and Schouten, 1986; and references cited in text). SGBfz-Southern Grand Banks fracture zone (transform); SGb-South Georgia basin. 
into the Tennessee embayment; then, on the New York promontory followed by migration into the Pennsylvania embayment; and finally, in the Quebec embayment (Bradley, 1989, Figures 1 and 7 therein). Taconic terrane accretion must have modified the shape of the margin; however, initial Acadian foreland subsidence migrated progressively southward from the St. Lawrence promontory to the Virginia promontory (Ettensohn, 1985, Figures 1 and 2 therein). Along the Appalachian orogen, late Paleozoic Alleghanian foreland subsidence overprinted the Taconic and Acadian forelands; however, along the Ouachita margin westward from the corner of the Alabama promontory, a passive margin persisted until Mississippian time (Thomas, 1989). Ouachita tectonic loading of the Laurentian margin began in middle Mississippian time in the Black Warrior foreland basin along the southeastern part of the Alabama-Oklahoma transform on the Alabama promontory and migrated northwestward along the transform to the Arkoma foreland basin in the Ouachita embayment in Early Pennsylvanian time (Fig. 4) (Houseknecht, 1986; Thomas, 1989), continuing the pattern of adaptation of the shape of the orogen to that of the Iapetan rifted margin.

Regardless of the diachroneity of foreland subsidence and synorogenic sedimentation along the orogen, maximum subsidence, as indicated by maximum thickness of synorogenic sediment along the Taconic, Acadian, and Alleghanian forelands, is centered consistently in embayments of the Iapetan rifted margin (Fig. 4) (Thomas, 1977, Figures 5-10 therein). Although the differences in the magnitude of subsidence could reflect along-strike variations in the magnitude of the tectonic loads, the systematic relationship of differentially greater foreland subsidence in the embayments than on the promontories suggests a systematic spatial variation in the strength of the lithosphere in relation to the shape of the older rifted margin. Brittle structures in the shallow crust define the shape of the rifted continental margin; however, the distribution of magnitudes of foreland subsidence suggests tectonic inheritance at a lithospheric scale.

In addition to thrust-belt curvature convex toward the craton, where thrustbelt salients bend around embayments of the rifted margin, the thrust belt propagated to a greater width and farther cratonward in salients than in recesses (Fig. 4). The geometry of the salients adapted to the greater thickness of sedimentary cover and to greater depth to crystalline basement rocks beneath foreland basins in the embayments. Along the Appalachian orogen, the thin-skinned décollement in salients is within the Paleozoic sedimentary cover succession above Precambrian crystalline basement rocks. On some promontories along the arms of thrust-belt recesses, the Appalachian allochthon incorporates crystalline basement rocks in external basement massifs (Fig. 4), indicating that the décollement cuts down from the thick sedimentary cover in embayments along strike into basement rocks beneath a thinner sedimentary cover on promontories. Unconformable overstep of Silurian conglomerate onto basement rocks on the southern part of the New York promontory (Drake et al., 1989) indicates that the Taconic foreland, like the later Alleghanian foreland, incorporated an external basement massif on the promontory.

Synorogenic brittle reactivation of Iapetan synrift intracratonic faults inboard from the rifted margin is evident from the proximal to the distal foreland, indicating compressive stress from Appalachian-Ouachita orogenesis (e.g., Kolata and Nelson, 1991). The thin-skinned thrust belt includes both frontal and lateral ramps that rise above basement extensional faults and transverse faults, respectively (e.g., Thomas and Bayona, 2005). Reactivated faults and a southplunging arch overprinted the Iapetan Mississippi Valley graben (Thomas, 1991). Reactivation of the Southern Oklahoma fault system generated the ArbuckleWichita-Amarillo basement uplifts (Perry, 1989); the associated Anadarko basin along the fault system is among the deepest known cratonic basins.

In the Appalachian metamorphic internides, which include accreted terranes and internal basement massifs, orogen-parallel strike-slip faults (Gates et al., 1988) show no systematic adaptation to the shape of the older Iapetan rifted margin (Fig. 4), suggesting oblique collision, transpression, and orogen-parallel tectonic transport. The effects of tectonic inheritance evidently diminish outboard from the older rifted margin, probably because accretion of successive terranes modified the shape of the margin.

The latest episodes of Alleghanian foreland thrusting appear nonsystematically diachronous along the orogen. Although not precisely dated, the last of a succession of Alleghanian events around the Alabama promontory was continentcontinent collision with African continental crust, now marked by a suture beneath the Gulf Coastal Plain (Fig. 4). The suture is oblique to the Iapetan rifted margin, diverging eastward from the corner of the Alabama promontory. Continent-continent collision drove previously accreted terranes onto the continental shelf of the Alabama promontory, accounting for a diachronous succession of Ouachita and Appalachian thrusting (Thomas, 2004). The shape of the Iapetan margin, and not the shape of the collider, evidently controlled the orientation of Appalachian-Ouachita foreland structures.

Appalachian-Ouachita structures, from the scale of salients and recesses to foreland basins to individual thrust ramps and basement faults, have a clear pattern of tectonic inheritance from the trace and structures of the Iapetan rifted margin of eastern Laurentia. Most of the inherited structures are in the brittle, shallow crust; however, localization of maximum synorogenic flexural subsidence of the foreland in embayments of the Iapetan margin along transform faults (at oceanward concave intersections of transform faults with rift segments) suggests tectonic inheritance at a lithospheric scale. The assembly of Pangaea also set the mold for subsequent structures that formed during supercontinent breakup.

\section{BREAKUP OF PANGAEA AND OPENING OF THE ATLANTIC OCEAN}

Triassic grabens adjacent to the Atlantic Coastal Plain document inboard extension associated with the breakup of Pangaea, the opening of the modern Atlantic Ocean, and the isolation of the North American continent. Unlike the records of earlier Wilson cycles, this latest event is recorded in the modern continental shelf and ocean floor, including transform faults that extend from the Mid-Atlantic Ridge to offsets in the shelf margin (Fig. 5). In addition to the exposed Triassic faults, subsurface data 
document other Triassic faults beneath a post-rift unconformity at the base of the Mesozoic-Cenozoic passive-margin successions in the Atlantic and Gulf Coastal Plains (Fig. 5). The Triassic faults are analogous to the intracratonic faults associated with Iapetan rifting.

The trace of the rifted continental margin includes promontories and embayments analogous to those of the Iapetan margin. The Bahamas fracture zone (transform fault) offsets the continental margin from the Florida promontory into the Gulf embayment; along the Gulf margin, a northwest-trending alignment of Triassic faults parallels the transform (Fig. 5). The traces of the Bahamas transform and the Triassic faults are aligned with the trace of the Iapetan AlabamaOklahoma transform in a clear expression of large-scale tectonic inheritance (Thomas, 1988).

The width of transitional crust differs on opposite sides of the Gulf of Mexico, suggesting a lower-plate structure on the Texas-Louisiana margin (Buffler and Thomas, 1994). The attenuated lowerplate crustal structure overprints the Ouachita accretionary complex (Keller et al., 1989), suggesting the possibility that distinctive crustal properties may be inherited by the geometry of continental rifting. Deep subsidence of the lower plate along the Bahamas transform within the Gulf embayment accommodated the very thick accumulation of sediment in the Mississippi River delta, inheriting the location of the Iapetan Ouachita embayment and the Pangaean Ouachita thrust-belt salient.

The Bahamas transform reoccupied the position of the older Alabama-Oklahoma transform; however, the Atlantic rifted margin of North America crosses Pangaean sutures and does not follow older Iapetan rift segments (Fig. 5). The Bahamas transform and the Triassic faults cross the Pangaean Suwannee suture; however, the fault boundaries of the Triassic South Georgia basin approximately parallel the Suwannee suture. Northward from the Bahamas transform, the Atlantic rifted margin follows neither the Iapetan rifted margin nor Pangaean sutures; instead, it is outboard of the Iapetan rift, leaving accreted African crust of the Suwannee terrane attached to North America, forming the Florida promontory.
The Southern Grand Banks fracture zone (transform) along the southern margin of the Grand Banks of Newfoundland (Keen and Haworth, 1985) is aligned with the trace of the Iapetan transform at the southern margin of the St. Lawrence promontory (Fig. 5). The trace of the Atlantic rifted margin east of the Grand Banks promontory roughly parallels the trace of the Iapetan rifted margin, but it is far outboard of the Iapetan rift, leaving accreted terranes attached to the North American margin, a pattern that persists southward to the Florida promontory.

Tectonic inheritance on a large scale is reflected in the coincidence in location of large transform offsets of the rifted continental margins. The extraordinary subsidence and sediment accumulation in the Mississippi River delta along the Bahamas fracture zone (transform) within the Gulf embayment is comparable to other examples of differentially greater subsidence along transforms. Inboard from the Bahamas transform margin, subsidence of the Mississippi Embayment, a south-plunging syncline in the Gulf Coastal Plain, overprints the Pangean (late Paleozoic) south-plunging arch and the Iapetan intracratonic Mississippi Valley graben, documenting successive inheritance at a pervasive zone of weak crust. The same zone of weak crust hosts the modern New Madrid seismic zone. On a smaller scale, Atlantic-opening extensional faults reactivated accretionary compressional fabrics of the Pangaean assembly (e.g., Bobyarchick and Glover, 1979).

\section{CONCLUSIONS}

Transform faults and aligned compressional structures show repeated tectonic inheritance through successive Wilson cycles of supercontinent assembly and breakup (Fig. 1). In contrast, rift segments of continental margins accumulate accreted terranes, because subsequent rifts break across terrane boundaries, fragmenting the supercontinent assembly. Brittle extensional structures and upper-crustal orogenic structures reflect processes in the shallow crust, as do the many examples of smaller scale tectonic inheritance and reactivation of individual faults. Two relationships, however, suggest inheritance at a lithospheric scale: successive reoccupation of traces of transform faults at the continental margin and differential crustal subsidence along transform faults at rift offsets in continental embayments. A pervasive fabric may vertically partition the lithosphere, both controlling the locations of transforms during successive events of supercontinent breakup and reducing the elastic strength of the lithosphere along transforms, thereby accounting for locations of greatest differential subsidence.

Kinematics of plate boundaries require that transform faults are small circles around the pole of rotation, are parallel to the direction of plate motion, and are essentially vertical, consistent with extent down through the lithosphere. In contrast, rift segments are brittle upper-crustal structures above low-angle detachments that flatten downward within the crust, consistent with inheritance at the scale of individual faults in shallow (brittle) crust.

Recognition of tectonic inheritance has implications for a range of applications beyond the fundamental questions of crustal structure and evolution of continental crust and lithosphere. Differential subsidence at zones of lithospheric weakness, primarily along transform systems, localizes the potential for petroleum provinces in exceptionally thick sedimentary accumulations. Mineralizing brines may be selectively driven from the thicker sedimentary thrust loads in thrust-belt salients at rift-margin embayments, including into the distal foreland. On a smaller scale, frontal thrust ramps over older basement faults, thin-skinned transverse zones over basement transverse faults, and reactivation of basement faults in the foreland provide predictable controls on fracture sets that affect fluid flow in both petroleum and groundwater systems. Repeated inheritance of zones of crustal weakness suggests a focus for modern seismicity.

Studies of tectonic inheritance generally rely on data from the shallow crust, limiting evaluations to a crustal scale. The pervasiveness of zones of crustal weakness associated with transform faults, however, requires a lithospheric scale of investigation. Recent studies of seismic anisotropy define lithospherepenetrating zones of distributed shear along transform systems (e.g., Baldock and Stern, 2005). The probable significance of transform inheritance and lithospheric properties suggests a fruitful line 
of investigation, because transform faults appear to be the dominant controls on tectonic inheritance at large scales along continental margins during supercontinent breakup and assembly, as well as on locations of differential subsidence and exceptionally thick sediment accumulations. Resolution of the lithospheric structure of transform faults in the context of tectonic inheritance offers an exciting new perspective and understanding of the evolution of continental crust and lithosphere.

\section{ACKNOWLEDGMENTS}

I thank Bob Hatcher, Randy Keller, Dave Moecher, Ed Osborne, and Rob Van der Voo for helpful reviews of drafts of this manuscript.

\section{REFERENCES CITED}

Aleinikoff, J.N., Zartman, R.E., Walter, M., Rankin, D.W., Lyttle, P.T., and Burton, W.C., 1995, U$\mathrm{Pb}$ age of metarhyolites of the Catoctin and Mount Rogers Formations, central and southern Appalachians: Evidence for two pulses of lapetan rifting: American Journal of Science, v. 295, p. 428-454.

Baldock, G., and Stern, T., 2005, Width of mantle deformation across a continental transform: Evidence from upper mantle $(\mathrm{Pn})$ seismic anisotropy measurements: Geology, v. 33, p. 741-744, doi: 10.1130/G21605.1.

Bobyarchick, A.R., and Glover, L., III, 1979 Deformation and metamorphism in the Hylas zone and adjacent parts of eastern Piedmont in Virginia: Geological Society of America Bulletin, v. 90, p. 739-752, doi: 10.1130/0016 7606(1979)90<739:DAMITH>2.0.CO;2.

Bowring, S., 1984, U-Pb zircon ages of granitic boulders in the Ordovician Blakely Sandstone, Arkansas, and implications for their provenance, in Stone, C.G., and Haley, B.R., eds., A guidebook to the geology of the central and southern Ouachita Mountains, Arkansas: Arkansas Geological Commission Guidebook 84-2, p. 123.

Bradley, D.C., 1989, Taconic plate kinematics as revealed by foredeep stratigraphy, Appalachian orogen: Tectonics, v. 8, p. 1037-1049.

Buffler, R.T., and Thomas, W.A., 1994, Crustal structure and evolution of the southeastern margin of North America and the Gulf of Mexico basin, in Speed, R.C., ed., Phanerozoic evolution of North American continent-ocean transitions: Geological Society of America, Decade of North American Geology, Continent-Ocean Transect Volume, p. 219-264

Cawood, P.A., and Nemchin, A.A., 2001, Paleogeographic development of the east Laurentian margin: Constraints from U-Pb dating of detrital zircons in the Newfoundland Appalachians: Geological Society of America Bulletin v. 113 , p. 1234-1246, doi: 10.1130/00167606(2001)113<1234:PDOTEL>2.0.CO;2.

Cawood, P.A., McCausland, P.J.A., and Dunning, G.R., 2001, Opening lapetus: Constraints from the Laurentian margin in Newfoundland: Geologica Society of America Bulletin, v. 113, p. 443-453, doi: 10.1130/0016-7606(2001)113<0443: OICFTL $>2.0 . C O ; 2$

Denison, R.E., 1982, Geologic cross section from the Arbuckle Mountains to the Muenster arch southern Oklahoma and Texas: Geological Society of America Map and Chart Series MC-28R, 8 p

Drahovzal, J.A., Harris, D.C., Wickstrom, L.H., Walker, D., Baranoski, M.T., Keith, B.D., and Furer, L.C. 1992, The East Continent rift basin: A new dis- covery: Kentucky Geological Survey Special Publication 18, 25 p.

Drake, A.A., Jr., Sinha, A.K., Laird, J., and Guy, R.E., 1989, The Taconic orogen, in Hatcher, R.D., Jr., Thomas, W.A., and Viele, G.W., eds., The Appalachian-Ouachita orogen in the United States: Geological Society of America, The Geology of North America, v. F-2, p. 101-177.

Ettensohn, F.R., 1985, The Catskill delta complex and the Acadian orogeny: A model: Geological Society of America Special Paper 201, p. 39-49.

Gates, A.E., Speer, J.A., and Pratt, T.L., 1988, The Alleghanian southern Appalachian Piedmont: A transpressional model: Tectonics, v. 7, p. 13071324.

Hatcher, R.D., Jr., Thomas, W.A., Geiser, P.A., Snoke, A.W., Mosher, S., and Wiltschko, D.V., 1989 Alleghanian orogen, in Hatcher, R.D., Jr., Thomas, W.A., and Viele, G.W., eds., The AppalachianOuachita orogen in the United States: Geological Society of America, The Geology of North America, v. F-2, p. 233-318.

Hatcher, R.D., Jr., Bream, B.R., Miller, C.F., Eckert, J.O., Jr., Fullagar, P.D., and Carrigan, C.W., 2004, Paleozoic structure of internal basement massifs, southern Appalachian Blue Ridge, incorporating new geochronologic, $\mathrm{Nd}$ and $\mathrm{Sr}$ isotopic, and geochemical data, in Tollo, R.P., et al., eds., Proterozoic tectonic evolution of the Grenville orogen in North America: Geological Society of America Memoir 197, p. 525-547.

Hoffman, P.F., 1989, Precambrian geology and tectonic history of North America, in Bally, A.W. and Palmer, A.R., eds., The Geology of North America-An overview: Geological Society of America, The Geology of North America, v. A, p. 447-512.

Hoffman, P.F., 1991, Did the breakout of Laurentia turn Gondwanaland inside-out?: Science, v. 252, p. 1409-1412.

Hogan, J.P., and Gilbert, M.C., 1998, The Southern Oklahoma aulacogen: A Cambrian analog for mid-Proterozoic AMCG (anorthosite-mangeritecharnockite-granite) complexes?, in Hogan, J.P., and Gilbert, M.C., eds., Central North America and other regions: Dordrecht/Boston, Kluwer, Proceedings of the Twelfth International Conference on Basement Tectonics, p. 39-78.

Houseknecht, D.W., 1986, Evolution from passive margin to foreland basin: The Atoka Formation of the Arkoma basin, south-central U.S.A.: International Association of Sedimentologists Special Publication 8, p. 327-345.

Kay, S.M., Orrell, S., and Abbruzzi, J.M., 1996, Zircon and whole rock $\mathrm{Nd}-\mathrm{Pb}$ isotopic evidence for a Grenville age and a Laurentian origin for the basement of the Precordillera in Argentina: Journal of Geology, v. 104, p. 637-648.

Keen, C.E., and Haworth, R.T., 1985, D-2 Transform margin south of Grand Banks: Offshore eastern Canada: Geological Society of America Centennial Continent-Ocean Transect \#2, 6 p., 1 sheet.

Keller, G.R., Braile, L.W McMechan, G.A., Thomas, W.A., Harder, S.H., Chang, W.-F., and Jardine, W.G., 1989, Paleozoic continent-ocean transition in the Ouachita Mountains imaged from PASSCAL wide-angle seismic reflection-refraction data: Geology, v. 17, p. 119-122, doi: 10.1130/00917613(1989)017<0119:PCOTIT >2.3.CO;2.

King, E.R., and Zietz, I., 1978, The New York-Alabama lineament: Geophysical evidence for a major crustal break in the basement beneath the Appalachian basin: Geology, v. 6, p. 312318, doi: 10.1130/0091-7613(1978)6<312: TNYLGE $>2.0 . \mathrm{CO} ; 2$

Klitgord, K.D., and Schouten, H., 1986, Plate kinematics of the central Atlantic, in Vogt, P.R., and Tucholke, B.E., eds., The western North Atlantic region: Geological Society of America, The Geology of North America, v. M, p. 351-378.

Kolata, D.R., and Nelson, W.J., 1991, Tectonic history of the Illinois basin, in Leighton, M.W., Kolata,
D.R., Oltz, D.F., and Eidel, J.J., eds., Interior cratonic basins: American Association of Petroleum Geologists Memoir 51, p. 263-285

Lister, G.S., Etheridge, M.A., and Symonds, P.A., 1986 Detachment faulting and the evolution of passive continental margins: Geology, v. 14, p. 246250, doi: 10.1130/0091-7613(1986)14<246: DFATEO $>2.0 . C O ; 2$.

Loewy, S.L., Connelly, J.N., and Dalziel, I.W.D., 2002, $\mathrm{Pb}$ isotopes as a correlation tool to constrain Rodinia reconstruction: Geological Society of America Abstracts with Programs, v. 34, no. 6, p. 558 .

McLelland, J., Daly, J.S., and McLelland, J.M., 1996, The Grenville orogenic cycle (ca. 1350-1000 Ma): An Adirondack perspective: Tectonophysics, v. 265, p. 1-28, doi: 10.1016/S0040-1951(96)00144-8.

Mosher, S., 1998, Tectonic evolution of the southern Laurentian Grenville orogenic belt: Geological Society of America Bulletin, v. 110, p. 13571375, doi: 10.1130/0016-7606(1998)110<1357: TEOTSL $>2.3$. CO; 2 .

Osberg, P.H., Tull, J.F., Robinson, P., Hon, R., and Butler, J.R., 1989, The Acadian orogen, in Hatcher, R.D., Jr., Thomas, W.A., and Viele, G.W., eds., The Appalachian-Ouachita orogen in the United States: Geological Society of America, The Geology of North America, v. F-2, p. 179-232.

Owens, B.E., and Tucker, R.D., 2003, Geochronology of the Mesoproterozoic State Farm gneiss and associated Neoproterozoic granitoids, Goochland terrane, Virginia: Geological Society of America Bulletin, v. 115, p. 972-982, doi: 10.1130/ B25258.1.

Perry, W.J., Jr., 1989, Tectonic evolution of the Anadarko basin region, Oklahoma: U.S. Geological Survey Bulletin 1866, A19 p.

Rankin, D.W., 1976, Appalachian salients and recesses: Late Precambrian continental breakup and opening of the lapetus Ocean: Journal of Geophysical Research, v. 81, p. 5605-5619.

Santos, J.O.S., Hartmann, L.A., McNaughton, N.J., Easton, R.M., Rea, R.G., and Potter, P.E., 2002, Sensitive high resolution ion microprobe (SHRIMP) detrital zircon geochronology provides new evidence for a hidden Neoproterozoic foreland basin to the Grenville orogen in the eastern Midwest, U.S.A.: Canadian Journal of Earth Sciences, v. 39, p. 1505-1515, doi: 10.1139/ e02-052.

Thomas, W.A., 1976, Evolution of OuachitaAppalachian continental margin: Journal of Geology, v. 84, p. 323-342.

Thomas, W.A., 1977, Evolution of AppalachianOuachita salients and recesses from reentrants and promontories in the continental margin: American Journal of Science, v. 277, p. 12331278.

Thomas, W.A., 1983, Continental margins, orogenic belts, and intracratonic structures: Geology, v. 11 , p. 270-272, doi: 10.1130/0091 7613(1983)11<270:CMOBAl>2.0.CO;2.

Thomas, W.A., 1988, Early Mesozoic faults of the northern Gulf Coastal Plain in the context of opening of the Atlantic Ocean, in Manspeizer, W., ed., Triassic-Jurassic rifting: Amsterdam, Elsevier, p. 461-476.

Thomas, W.A., 1989, The Appalachian-Ouachita orogen beneath the Gulf Coastal Plain between the outcrops in the Appalachian and Ouachita Mountains, in Hatcher, R.D., Jr., Thomas, W.A., and Viele, G.W., eds., The Appalachian-Ouachita orogen in the United States: Geological Society of America, The Geology of North America, v. F2, p. 537-553.

Thomas, W.A., 1991, The Appalachian-Ouachita rifted margin of southeastern North America: Geological Society of America Bulletin, v. 103, p. 415-431, doi: 10.1130/0016-7606(1991)103<0415: TAORMO $>2.3 . \mathrm{CO} ; 2$.

Thomas, W.A., 1993, Low-angle detachment geometry of the late Precambrian-Cambrian Appalachian-Ouachita rifted margin of southeastern North America: Geology, v. 21, p. 921- 


\section{GSA PRESIDENTIAL ADDRESS}

924, doi: 10.1130/0091-7613(1993)021<0921: LADGOT>2.3.CO;2.

Thomas, W.A., 2004, Genetic relationship of rift-stage crustal structure, terrane accretion, and foreland tectonics along the southern AppalachianOuachita orogen: Journal of Geodynamics, v. 37 p. 549-563, doi: 10.1016/j.jog.2004.02.020.

Thomas, W.A., and Astini, R.A., 1996, The Argentine Precordillera: A traveler from the Ouachita embayment of North American Laurentia: Science, v. 273 p. $752-757$.

Thomas, W.A., and Astini, R.A., 1999, Simpleshear conjugate rift margins of the Argentine Precordillera and the Ouachita embayment of Laurentia: Geological Society of America Bulletin, v. 111, p. 1069-1079, doi: 10.1130/00167606(1999) $111<1069:$ SSCRMO $>2.3 . \mathrm{CO} \cdot 2$

Thomas, W.A., and Bayona, G., 2005, The Appalachian thrust belt in Alabama and Georgia: Thrust-bel structure, basement structure, and palinspastic reconstruction: Geological Survey of Alabama Monograph 16, 48 p., 2 plates.

Thomas, W.A., Viele, G.W., Arbenz, J.K., Nicholas, R.L., Denison, R.E., Muehlberger, W.R., and Tauvers, P.R., 1989, Tectonic map of the Ouachita orogen in Hatcher, R.D., Jr., Thomas, W.A., and Viele, G.W., eds., The Appalachian-Ouachita orogen in the United States: Geological Society of America, The Geology of North America, v. F-2, plate 9.
Thomas, W.A., Tucker, R.D., and Astini, R.A., 2000, Rifting of the Argentine Precordillera from southern Laurentia: Palinspastic restoration of basement provinces: Geological Society of America Abstracts with Programs, v. 32, no. 7, p. A-505.

Van Schmus, W.R., Bickford, M.E., Anderson, J.L., Bender, E.E., Anderson, R.R., Bauer, P.W., Robertson, J.M., Bowring, S.A., Condie, K.C. Denison, R.E., Gilbert, M.C., Grambling, J.A., Mawer, C.K., Shearér, C.K., Hinze, W.J. Karlstrom, K.E., Kisvarsanyi, E.B., Lidiak, E.G. Reed, J.C., Jr., Sims, P.K., Tweto, O., Silver, L.T., Treves, S.B., Williams, M.L., and Wooden, J.L., 1993, Transcontinental Proterozoic provinces, in Reed, J.C., Jr., et al., eds., Precambrian: Conterminous U.S.: Geological Society of America, The Geology of North America, v. C-2, p. 171-334.

Wilson, J.T., 1966, Did the Atlantic close and then reopen?: Nature, v. 211, p. 676-681.

Prepared from the Presidential Address delivered at the 2005 GSA Annual Meeting E Exposition in Salt Lake City, Utah, on 15 October 2005.

THE GEOLOGICAL SOCIETY OF AMERICA 